\title{
Kekerasan Terhadap Anak dalam Perspektif Kriminologi Di Kecamatan Tobelo Kabupaten Halmahera Utara
}

\author{
Ernest Sengi $^{*}$, Alfonsisus Budiman ${ }^{2}$ \\ ${ }^{1,2}$ Fakultas Ilmu Sosial dan Humaniora Universitas Halmahera \\ Maluku Utara, Tobelo \\ *Correspondence email: ernestsengi@gmail.com; alfonsisusbudiman@gmail.com
}

\begin{abstract}
Abstrak. Anak merupakan generasi penerus bangsa yang perlu dilindungi dari berbagai bentuk kekerasan. Lahirnya undangundang penghapusan kekerasan dalam rumah tangga dan undang-undang perlindungan anak tidak selalu berbanding lurus pada hilangnya perilaku kekerasan terhadap anak. Dalam tulisan ini, isu hukum yang akan dikaji adalah bagaimana perspektif kriminologi dalam menanggulangi kekerasan terhadap anak di Kecamatan Tobelo Kabupaten Halmahera Utara. Kemudian, untuk menjawab isu hukum tersebut digunakan metode penelitian hukum yuridis empiris dengan pendekatan sosiologi hukum yang didukung dengan pendekatan undang-undang. Pendekatan ini dipandang tepat karena akan diuraikan data kasus kekerasan terhadap anak di Kecamatan Tobelo kemudian dari data tersebut akan dianalisis untuk mendapat preskripsi hukum tentang bagaimana kriminologi memandang berbagai bentuk kekerasan terhadap anak. Hasil penelitian menunjukan bahwa Tahun 2015 hingga Tahun 2018 di Kecamatan Tobelo, Kabupaten Halmahera Utara, terdapat 57 kasus kekerasan terhadap anak. Selain itu, kekerasan terhadap anak terbukti merupakan suatu bentuk tindak pidana dimana pelaku dapat dimintai pertanggungjawaban pidana baik melalui pidana umum maupun pidana khusus.
\end{abstract}

Kata Kunci: Kekerasan; Anak; Kecamatan Tobelo

\begin{abstract}
Children are the nation's next generation who need to be protected from various forms of violence. The enactment of the law on the elimination of violence in household and the child protection law does not always directly proportional to the loss of violent behavior towards children. In this paper, the legal issue that will be examined is how the perspective of criminology in overcoming violence against children in Tobelo Subdistrict North Halmahera Regency. Then, to answer the legal issues used nondoctrinal legal research methods with a socio legal research approach that is supported by the statute approach. This approach is considered appropriate because the data on cases of violence against children in Tobelo sub-district will be described and then analyzed from this data to obtain a legal prescription on how the criminology views various forms of violence against children. The results showed that in 2015 to 2018 in Tobelo Subdistrict, North Halmahera Regency, there were 57 cases of violence against children. Besides, violence against children is a form of criminal activity in which the offender can be held liable either through general or special crimes.
\end{abstract}

Keywords: Violence; Children; Tobelo District

\section{PENDAHULUAN}

Negara Indonesia adalah negara hukum; demikian ditegaskan dalam Pasal 1 ayat (3) UUD NRI 1945 sebagai konstitusi dasar tertinggi. Pengakuan oleh negara bahwa hukum menjadi panglima tertinggi tersebut memberikan pengakuan dan pegangan bagi segenap bangsa Indonesia bahwa dalam segala aktivitasnya harus berdasarkan normanorma hukum yang menjadi pedoman hidup; termasuk pedoman bagi negara atau penguasa untuk tidak bertindak sewenang-wenang dalam mengatur masyarakat. Konsep tentang hal ini dikenal dengan asas legalitas; suatu asas yang menghendaki bahwa setiap perbuatan yang dilakukan, perbuatan tersebut telah harus lebih dahulu diatur dalam suatu peraturan perundang-undangan secara tertulis; dan jika tidak, maka perbuatan tersebut dikategorikan sebagai suatu perbuatan melawan hukum.

Salah satu ciri suatu negara hukum adalah adanya perlindungan hak asasi manusia. Konsep negara hukum akan menjadi percuma jika hak asasi manusia tidak mendapat perlindungan dari negara. Hak asasi manusia dalam aspek yang luas dapat tercermin dari berbagai macam hak di antaranya hak hidup, hak di bidang sosial, hak di bidang ekonomi, hak di bidang pendidikan, hak di bidang politik, hak mendapat perlindungan, rasa aman dan hak-hak lain.

Menerjemahkan kata "manusia" dalam konsep hak asasi manusia, tidak hanya orang dewasa melainkan juga anak-anak yang merupakan generasi penerus bangsa. Oleh sebab itu, perlindungan hak asasi manusia oleh negara dalam konsep negara hukum, termasuk juga di dalamnya perlindungan atas hak asasi anak. Dengan demikian, mengabaikan perlindungan hak-hak asasi anak, sama halnya dengan mengabaikan perintah konstitusi negara.

Kepentingan terbaik bagi anak (the best interest for the child), merupakan slogan yang selalu dikemukakan ketika membicarakan soal perlindungan anak. Hal tersebut adalah tepat karena anak merupakan manusia lemah yang perlu mendapat perhatian dan perlindungan khusus terutama perlindungan dari bentuk kekerasan apapun dan dari siapapun termasuk dari lingkungan terdekat sekalipun. Menurut data Komisi Perlindungan Anak Indonesia (KPAI), 
tujuh puluh persen $(70 \%)$ pelaku kekerasan terhadap anak dilakukan oleh orang terdekat termasuk orang tua ${ }^{1}$. Hal tersebut mengandung arti bahwa kekerasan terhadap anak rentan dilakukan oleh orang - orang yang berada di lingkungan terdekat. Kekerasan terhadap anak merupakan jenis kekerasan yang menyentuh berbagai aspek kehidupan manusia baik aspek sosial, aspek moral, keagamaan maupun aspek hukum. Oleh sebab itu, kekerasan terhadap anak sudah termasuk kategori kejahatan serius. Karena tingkat berbahaya dan akibat yang ditimbulkan oleh tindakan kekerasan tersebut sudah merupakan kejahatan serius maka negara dituntut berpartisipasi aktif dalam melihat persoalan ini.

Sebagai bentuk respon negara atas tindakan kekerasan terhadap anak, negara telah mengeluarkan Undang Undang Nomor 35 Tahun 2014 tentang perubahan atas Undang - Undang Nomor 23 Tahun 2002 tentang Perlindungan Anak serta Undang - Undang Nomor 23 Tahun 2004 tentang Penghapusan Kekerasan Dalam Rumah Tangga; selain itu terdapat juga Kitab Undang - Undang Hukum Pidana yang dijadikan sebagai payung hukum dalam mencegah dan menindak pelaku kekerasan terhadap anak. Arti kata "Perlindungan" yang diberi lebel dalam undang-undang ini mengandung filosofi yang mendalam dimana setiap warga negara terutama anak berhak mendapat rasa aman dan bebas dari segala bentuk kekerasan.

Bentuk kekerasan terhadap anak yang biasanya terjadi di antaranya kekerasan fisik, kekerasan psikis, kekerasan seksual dan penelantaran; hal-hal tersebut termasuk dalam ranah perbuatan pidana dimana pelaku kekerasan dapat dikenai sanksi pidana dalam peraturan pidana umum maupun peraturan pidana khusus. Berkaitan dengan hal tersebut, menurut Simons sebagaimana dikutip Adami Chazawi ${ }^{2}$ bahwa perbuatan pidana atau straafbaar feit adalah suatu tindakan melanggar hukum yang dengan sengaja telah dilakukan oleh seorang yang dapat dipertanggungjawabkan atas tindakannya, yang dinyatakan sebagai dapat dihukum. Dengan demikian, maka setiap perbuatan kekerasan terhadap anak merupakan perbuatan pidana dimana pelaku dapat dimintai pertanggujawaban secara hukum.

Meskipun sudah ada pengaturan terkait kekerasan terhadap anak dengan ancaman sanksi hukum pidana yang tegas, namun kekerasan terhadap anak masih saja terjadi dalam masyarakat di Kecamatan Tobelo Kabupaten Halmahera Utara. Data awal yang dicatat oleh Dinas Perlindungan Perempuan dan Anak Kabupaten Halmahera Utara menunjukan bahwa kasus kekerasan anak dalam empat tahun terakhir terus mengalami perubahan, untuk tahun 2015 ada (8 kasus), tahun 2016 (12 kasus), tahun 2017 (22 kasus) dan tahun 2018 (15) kasus ${ }^{3}$. Jumlah data tersebut pun tidak termasuk beberapa kasus lainnya yang tidak dilaporkan secara resmi karena telah diselesaikan di tingkat desa atau karena suatu budaya masyarakat Halmahera yang menganggap sebagai aib keluarga; situasi seperti ini menurut Harkristuti Harkrisnowo sebagaimana dikutip Mahmudin Kobandaha menyebabkan tingginya "the dark number" karena tidak dilaporkan ${ }^{4}$.

Data tersebut menunjukan bahwa kasus kekerasan terhadap anak merupakan fenomena gunung es yang akan terus meningkat jika tidak ditangani. Banyak faktor yang diduga sebagai penyebab terjadinya kekerasan terhadap anak mulai dari faktor sosial/lingkungan, ekonomi, budaya, dan faktor lainnya yang dapat dibuktikan nanti melalui penelitian ini. Dimana fokus yang menjadi sasaran penelitian adalah beberapa desa yang berada dalam wilayah Kecamatan Tobelo yang menjadi titik selalu terjadinya kekerasan terhadap anak di Kabupaten Halmahera Utara, dimana hukum pidana dan khususnya kriminologi akan dijadikan sebagai alat untuk menganalisisnya.

Hukum pidana merupakan salah satu disiplin ilmu hukum yang mengkaji tentang kejahatan dan pelanggaran terhadap kepentingan umum. Menurut Bambang Waluyo ${ }^{5}$, secara sederhana dapat dikemukakan bahwa hukum pidana merupakan hukum yang mengatur tentang perbuatan - perbuatan yang dilarang oleh undang - undang beserta sanksi pidana yang dapat dijatuhkan kepada pelaku. Sementara kriminologi, merupakan cabang ilmu hukum pidana yang khusus mempelajari sebab-sebab terjadinya kejahatan dan reaksi masyarakat atas kejahatan.

Tulisan ini akan menggunakan disiplin cabang ilmu hukum pidana yakni kriminologi untuk menganalisis berbagai kasus kekerasan terhadap anak di Kecamatan Tobelo Kabupaten Halmahera Utara; dimana dalam hal-hal tertentu hukum pidana seringkali tidak dapat digunakan untuk menyelesaikan kasus-kasus kekerasan terhadap anak karena lebih banyak pelaku dan korban memilih penyelesaian damai melalui musyawarah mufakat yang dikenal dengan istilah diversi oleh Undang - Undang Nomor 11 Tahun 2012 tentang Sistem Peradilan Pidana Anak. ${ }^{6}$ Konsep

${ }^{1}$ Penny Naluria Utami, "Pencegahan Kekerasan Terhadap Anak Dalam Perspektif Hak Atas Rasa Aman Di Nusa Tenggara Barat (Prevention Of Violence To Children From The Perspective Of The Rights To Security In West Nusa Tenggara" Jurnal HAM, Vol. 9, No. 1 (Juli 2018) : 9.

${ }^{2}$ Adami Chazawi, Pelajaran Hukum Pidana, Bagian 1, (Jakarta: Raja Grafindo Persada, 2002), hlm. 72.

${ }^{3}$ Laporan Dinas Perlindungan Perempuan, Perlindungan Anak dan Keluarga Berencana Kab. Halmahera Utara Tahun 2015 -2019 .

${ }^{4}$ Mahmudin Kobandaha, "Perlindungan Hukum Terhadap Anak Korban Kekerasan Dalam Rumah Tangga Dalam Sistem Hukum Di Indonesia" Jurnal Hukum Unsrat, Vol. 23, No. 8, (Januari 2017) : 85.

5 Bambang Waluyo, Pidana dan Pemidanaan, (Jakarta: Sinar Grafika, 2008), hlm. 6.

${ }^{6}$ Lihat Pasal 1 angka 7 UU No. 11 Tahun 2012, tentang Sistem Peradilan Pidana Anak. 
diversi tersebut sejalan dengan konsep keadilan bermartabat oleh Teguh Prasetyo ${ }^{7}$ yakni keadilan yang memanusiakan manusia baik pelaku maupun korban. Namun, dalam tulisan ini Penulis mencoba untuk melihat apakah hukum pidana dapat dijadikan sebagai parameter penyelesaian masalah kekerasan terhadap anak karena banyak kasus kekerasan terhadap anak justru terbentur dengan budaya masyarakat setempat, serta bagaimana kriminologi mengungkap sebabsebab terjadinya kekerasan terhadap anak di Kecamatan Tobelo Halmahera Utara.

Melalui kajian ini pula, akan dianalisis berbagai bentuk kekerasan terhadap anak yang terjadi di Kecamatan Tobelo Kabupaten Halmahera Utara melalui perspektif hukum pidana khususnya kriminologi dalam pengertian bagaimana norma hukum pidana melihat kasus - kasus kekerasan terhadap anak dalam hukum pidana positif Indonesia serta bagaimana kriminologi mengungkap penyebab kekerasan terhadap anak terus-menerus terjadi. Selain itu, Indonesia yang dikenal dengan multiculture sering terdapat perbedaan tentang suatu perbuatan dimana di daerah yang satu dikategorikan sebagai perbuatan pidana, sementara di daerah lain bukan merupakan suatu perbuatan pidana termasuk soal kekerasan terhadap anak.

\section{METODE}

Tujuan suatu penelitian hukum adalah memberikan solusi pemecahan masalah hukum (legal problem solving); hal ini sejalan dengan apa yang dikatakan Peter M. Marzuki ${ }^{8}$ bahwa penelitian hukum adalah suatu proses untuk menemukan aturan hukum, prinsip - prinsip hukum, maupun doktrin - doktrin hukum guna menjawab isu hukum yang dihadapi. Dengan demikian, diperlukan metode yang tepat untuk menjawab isu hukum yang diajukan. Sesuai isu hukum yang dibahas dalam tulisan ini, maka penelitian dalam tulisan ini merupakan penelitian hukum empiris atau non-doktrinal dengan menggunakan pendekatan socio legal research. Menurut Soerjono Soekanto dan Sri Mamudji ${ }^{9}$, penelitian empiris atau non-doktrinal mengkaji data primer dimana data dimaksud diperoleh dari masyarakat kemudian dianalisis dengan bahan-bahan hukum lain. Sejalan dengan hal tersebut, Bahder Johan Nasution ${ }^{10}$ menyebut penelitian hukum empiris bertujuan untuk mengetahui sejauhmana bekerjanya hukum di dalam masyarakat. Kaitannya dengan penelitian ini bahwa yang akan menjadi fokus kajian adalah data primer berupa pertama, kasus kekerasan terhadap anak di Kecamatan Tobelo Kabupaten Halmahera Utara yang terjadi selama empat (4) Tahun terakhir yakni Tahun 2015 sampai Tahun 2018; kedua, data wawancara yang dilakukan di beberapa desa di kecamatan Tobelo yang menjadi titik tingginya angka kekerasan anak. Selain itu, dibutuhkan juga data sekunder berupa regulasi peraturan perundang-undangan yang berkaitan dengan masalah yang diteliti yakni terkait kekerasan terhadap anak.

Setelah semua data terkumpul maka akan dilakukan analisis dengan menggunakan analisis deskripsi, evaluasi dan argumentasi. Teknik deskripsi yaitu suatu teknik analisis dalam penelitian yang bertujuan untuk menggambarkan secara mendalam mengenai suatu peristiwa. Kaitannya dengan penelitian ini, maka akan dilakukan analisis terhadap data primer dan mengaitkannya dengan data sekunder agar dapat menggambarkan secara jelas mengenai data kasus kekerasan anak di kecamatan Tobelo dan bagaimana perspektif hukum pidana dan kriminologi. Selanjutnya hasil analisis tersebut akan diberikan preskripsi hukum dengan menggunakan teknik evaluasi dan argumentasi.

\section{HASIL DAN PEMBAHASAN}

\section{Konsep dan Bentuk Kekerasan Anak}

Menurut Bagong sebagaimana dikutip oleh Thathit Manon Andini ${ }^{11}$ bahwa World Health Organization (WHO) mendefenisikan kekerasan adalah penggunaan kekuatan fisik dan kekuasaan, ancaman atau tindakan terhadap diri sendiri, perorangan atau sekelompok orang atau masyarakat yang mengakibatkan atau kemungkinan besar mengakibatkan memar/trauma, kematian, kerugian psikologis, kelainan perkembangan atau perampasan hak.

Kekerasan terhadap perempuan terutama anak, merupakan suatu perbuatan yang ditentang oleh semua manusia di dunia karena merupakan perbuatan yang merendahkan harkat dan martabat orang lain. Berkaitan dengan hal tersebut, terdapat berbagai istilah yang merujuk pada perbuatan kekerasan terhadap perempuan dan anak. Kekerasan yang korbannya adalah perempuan dikenal dengan istilah "violence against women, "gender based violence", "gender violence" dan "domestic violence; sementara kekerasan terhadap anak-anak dikenal dengan istilah "working children", "street childern", "childern in armed conflict" dan "urban war zones".

7 Teguh Prasetyo, "Penerapan Diversi Terhadap Tindak Pidana Anak Dalam Sistem Peradilan Pidana Anak", Jurnal Refleksi Hukum, Vol. 9, No. 1, (April 2015) : 6.

${ }^{8}$ Peter Mahmud Marzuki, Penelitian Hukum, (Jakarta: Kencana, 2005), hlm. 35.

9 Soerjono Soekanto dan Sri Mamudji, Penelitian Hukum Normatif, Suatu Tinjauan Singkat, (Jakarta: Raja Grafindo Persada, 2012), hlm. 12.

${ }^{10}$ Bahder Johan Nasution, Metode Penelitian Ilmu Hukum, (Bandung: Mandar Maju, 2008), hlm. 123.

${ }^{11}$ Thathit Manon Andini, dkk. "Identifikasi Kejadian Kekerasan pada Anak di Kota Malang Identification of Violence in Children in Malang City” Jurnal Perempuan dan Anak (JPA), Vol. 2, No. 1, (Februari 2019) : 15. 
Menurut John Hagan sebagaimana dikutip Warih Anjari ${ }^{12}$ kekerasan merupakan bentuk tindakan seseorang kepada pihak lain yang berakibat pada timbulnya rasa sakit dan perubahan baik fisik maupun psikis. Jika dikaitkan dengan kekerasan terhadap anak ketika dilihat dari perspektif perlindungan Hak Asasi Manusia, anak juga memiliki hak yang sama dengan manusia lainnya di muka bumi ini, yakni hak yang dipahami sebagai hak-hak yang melekat (inherent) secara alamiah sejak mereka dilahirkan dan tanpa itu anak tidak dapat hidup sebagai manusia secara wajar. Dengan demikian kehidupan anak perlu dilindungi dari berbagai bentuk kekerasan.

Kekerasan terhadap anak merupakan tanggungjawab semua pihak terutama negara. Kemajuan suatu negara sangatlah ditentukan oleh peran generasi penerus bangsa dalam bidang pembangunan; karena bagaimanapun juga perbuatan kekerasan terhadap anak dapat menghambat anak dalam proses pertumbuhan partisipasi sosial, ekonomi, politik, budaya dan kepercayaan diri sendiri dalam pertumbuhan jiwa serta masa depannya. Hal inilah sehingga Undang - Undang Nomor 23 Tahun 2002 sebagaimana telah dirubah dengan Undang - Undang Nomor 35 Tahun 2014 Tentang Perlindungan Anak memberikan kewajiban bagi negara untuk melindungi anak dari berbagai bentuk kekerasan.

Secara umum arti kekerasan juga digambarkan dalam Undang - Undang Nomor 23 Tahun 2004 tentang Penghapusan Kekerasan dalam Rumah Tangga yang menyebut bahwa kekerasan adalah setiap perbuatan terhadap seseorang terutama perempuan yang berakibat timbulnya kesengsaraan atau penderitaan secara fisik, seksual, psikologi dan/atau penelantaran rumah tangga termasuk ancaman melakukan perbuatan, pemaksaan atau perampasan kemerdekaan secara melawan hukum dalam lingkup rumah tangga. Rumah tangga dalam konsep undang - undang ini diartikan juga termasuk anak; sehingga melakukan kekerasan terhadap anak dalam lingkup rumah tangga, juga dapat dikenai undang - undang ini.

Berdasarkan kesadaran bahwa anak merupakan generasi penerus bangsa yang wajib dilindungi, maka kekerasan dalam bentuk apapun tidak boleh dilakukan terhadap anak. Hal ini sejalan dengan apa yang dikemukakan oleh Jhon D. Pasalbessy ${ }^{13}$ bahwa kekerasan merupakan sebuah terminologi yang sarat dengan arti dan makna "derita", baik dikaji dari perspektif psikologi maupun hukum, bahwa di dalamnya terkandung perilaku manusia (seseorang/kelompok orang) yang dapat menimbulkan penderitaan bagi orang lain, (pribadi/ kelompok) termasuk dalam hal ini anak. Dengan demikian konsep kekerasan dalam artikel ini dibatasi pada pengertian kekerasan dalam arti psikologis, kekerasan fisik dan kekerasan seksual terhadap anak dimana tidak diperbolehkan sama sekali dilakukan dengan alasan apapun.

Dalam penelitian yang ditulis oleh Piet Hein Babua ${ }^{14}$ kerja sama dengan Balitbang Kabupaten Halmahera Utara, diuraikan beberapa bentuk kekerasan terhadap anak yakni kekerasan fisik, kekerasan seksual, kekerasan emosional, penelantaran anak dan eskploitasi anak.

Berbagai jenis kekerasan tersebut terlihat bahwa bentuk - bentuk kekerasan yang terjadi pada anak dapat berupa kekerasan fisik dan kekerasan non-fisik. Hal ini lazim terjadi pada hampir semua kasus - kasus kekerasan anak yang diteliti.

\section{Faktor-Faktor Kekerasan Terhadap Anak}

Kekerasan terhadap anak dapat terjadi karena banyak faktor. Namun, berikut Penulis menguraikan beberapa faktor yang paling banyak ditemukan dalam hal terjadi kekerasan terhadap anak yang dibedakan atas faktor internal dan faktor eksternal.

Faktor internal merupakan faktor yang berasal dari dalam diri anak; dimana terjadinya kekerasan terhadap anak disebabkan oleh kondisi dan tingkah laku anak. Kondisi anak tersebut misalnya: Anak menderita gangguan perkembangan, ketergantungan anak pada lingkungannya, anak mengalami cacat tubuh, retardasi mental, gangguan tingkah laku, anak yang memiliki perilaku menyimpang dan tipe kepribadian dari anak itu sendiri. Keluarga atau orang tua Faktor orang tua atau keluarga memegang peranan penting terhadap terjadinya kekerasan pada anak. Beberapa contoh seperti orang tua yang memiliki pola asuh membesarkan anaknya dengan kekerasan atau penganiayaan, keluarga yang sering bertengkar mempunyai tingkat tindakan kekerasan terhadap anak yang lebih tinggi dibandingkan dengan keluarga yang tanpa masalah, orang tua tunggal lebih memungkinkan melakukan tindakan kekerasan terhadap anak karena faktor stres yang dialami orang tua tersebut, orang tua atau keluarga belum memiliki

12 Warih Anjari, "Fenomena Kejahatan Sebagai Bentuk Kekerasan (Violence)" Jurnal Widya Yustisia, Vol. 1, No. 1, (April 2014) : 43

13 Jhon D. Pasalbessy, "Dampak Tindak Kekerasan Terhadap Perempuan dan Anak Serta Solusinya” Jurnal Sasi, Vol. 16, No. 3, (Juli 2010) : 9.

${ }^{14}$ Piet Hein Babua, Kekerasan dalam Rumah Tangga di Kabupaten Halmahera Utara, (Tobelo: Balitabang Halut, Tahun 2018), hlm. 14. 
kematangan psikologis sehingga melakukan kekerasan terhadap anak, riwayat orang tua dengan kekerasan pada masa kecil juga memungkinkan melakukan kekerasan pada anaknya.

Faktor eksternal, merupakan faktor yang bersumber dari luar diri anak. Faktor ini dapat terjadi karena pengaruh lingkungan, media massa atau budaya masyarakat setempat yang mempengaruhi sikap dan tingkahlaku anak. seperti diketahui bahwa negara Indonesia terdiri dari berbagai suku dan budaya yang berbeda. Sering terjadi, suatu peristiwa disebut sebagai perbuatan pidana di satu daerah, sementara di daerah lain peristiwa tersebut bukanlah suatu perbuatan pidana melainkan suatu perbuatan biasa saja.

\section{Data Kasus Kekerasan Terhadap Anak di Kecamatan Tobelo}

Berdasarkan data jumlah kekerasan yang diperoleh di Kecamatan Tobelo, berikut diuraikan kategorisasi jumlah kekerasan terhadap anak melalui tabel dan garafik yang dibagi atas pertama jumlah kekerasan terhadap anak berdasarkan wilayah desa di Kecamatan Tobelo Kabupaten Halmahera Utara, jumlah kekerasan anak berdasarkan tingkat pendidikan dan tingkat usia korban. Hal ini dimaksud agar dapat dilakukan analisis dengan mudah berdasarkan data yang telah dideskripsikan.

Berikut diuraikan penyebaran jumlah kekerasan terhadap anak di Kecamatan Tobelo Kabupaten Halmahera Utara:

Tabel 1. Data Kasus Kekerasan Anak

\begin{tabular}{|c|c|c|c|}
\hline NO & NAMA DESA & JUMLAH KASUS & JENIS KASUS \\
\hline 1 & Wari & 6 & $\begin{array}{ll}\text { - } & 4 \text { Penelantaran } \\
\text { - } & 2 \text { Pemerkosaan }\end{array}$ \\
\hline 2 & War-Ino & 7 & $\begin{array}{l}\text { - } 6 \text { Penelantaran } \\
\text { - } 1 \text { Penganiayaan }\end{array}$ \\
\hline 3 & МKCM & 5 & - 5 Penganiayaan \\
\hline 4 & Gura & 4 & $\begin{array}{l}\text { - } 3 \text { Penganiayaan } \\
\text { - } 1 \text { Penelantaran }\end{array}$ \\
\hline 5 & Gamsungi & 5 & $\begin{array}{l}\text { - } 4 \text { Penganiayaan } \\
\text { - } 1 \text { Pelecehan }\end{array}$ \\
\hline 6 & Gosoma & 4 & $\begin{array}{l}\text { - } 3 \text { Penganiayaan } \\
\text { - } 1 \text { Pelecehan }\end{array}$ \\
\hline 7 & Wosia & 5 & $\begin{array}{l}\text { - } 2 \text { Penganiayaan } \\
\text { - } 3 \text { Penelantaran }\end{array}$ \\
\hline 8 & Mahia & 4 & - 4 Penelantaran \\
\hline 9 & Tanjung Niara & 4 & $\begin{array}{l}\text { - } 3 \text { Penganiayaan } \\
\text { - } 1 \text { Pelecehan }\end{array}$ \\
\hline 10 & Kumo & 3 & - 3 Penganiayaan \\
\hline 11 & Kakara & 4 & $\begin{array}{l}\text { - } 2 \text { Kekerasan psikis } \\
\text { - } 2 \text { Penganiayaan }\end{array}$ \\
\hline 12 & Rawajaya & 6 & $\begin{array}{l}\text { - } 4 \text { Penganiayaan } \\
\text { - } 2 \text { Penelantaran }\end{array}$ \\
\hline
\end{tabular}

Sumber: Dinas Perlindungan Perempuan, Perlindungan Anak dan Keluarga Berencana Kabupaten Halmahera Utara.

Data pada tabel tersebut menunjukan bahwa jenis kekerasan terhadap anak yang rentan terjadi di Kecamatan Tobelo Kabupaten Halmahera Utara adalah penganiayaan anak dengan total 34 kasus dan disusul dengan kasus penelantaran anak dengan total 16 kasus. Selain itu, ada pula jenis kekerasan anak yang berbentuk kekerasan seksual (Pemerkosaan dan Pelecehan) dengan total 5 kasus dan juga terdapat kekerasan psikis sebanyak 2 kasus; jadi total kasus kekerasan anak yang terjadi di Kabupaten Halmahera Utara dalam kurun waktu Tahun 2015 sampai Tahun 2018 adalah 57 kasus. Semua data tersebut telah dilaporkan dengan penyebaran untuk Tahun 2015 terdapat 8 kasus, Tahun 2016 terdapat 12 kasus, Tahun 2017 terdapat 22 kasus dan Tahun 2018 terdapat 15 kasus yang dilaporkan dan dicatat secara resmi oleh dinas Perlindungan Perempuan, Perlindungan Anak dan Keluarga Berencana Kabupaten Halmahera Utara.

Berdasarkan data sebagaimana tabel 1.1. tersebut, Penulis mencoba memberikan pemetaan korban kekerasan terhadap anak berdasarkan tingkat pendidikan dan berdasarkan usia anak korban kekerasan sebagai berikut: 


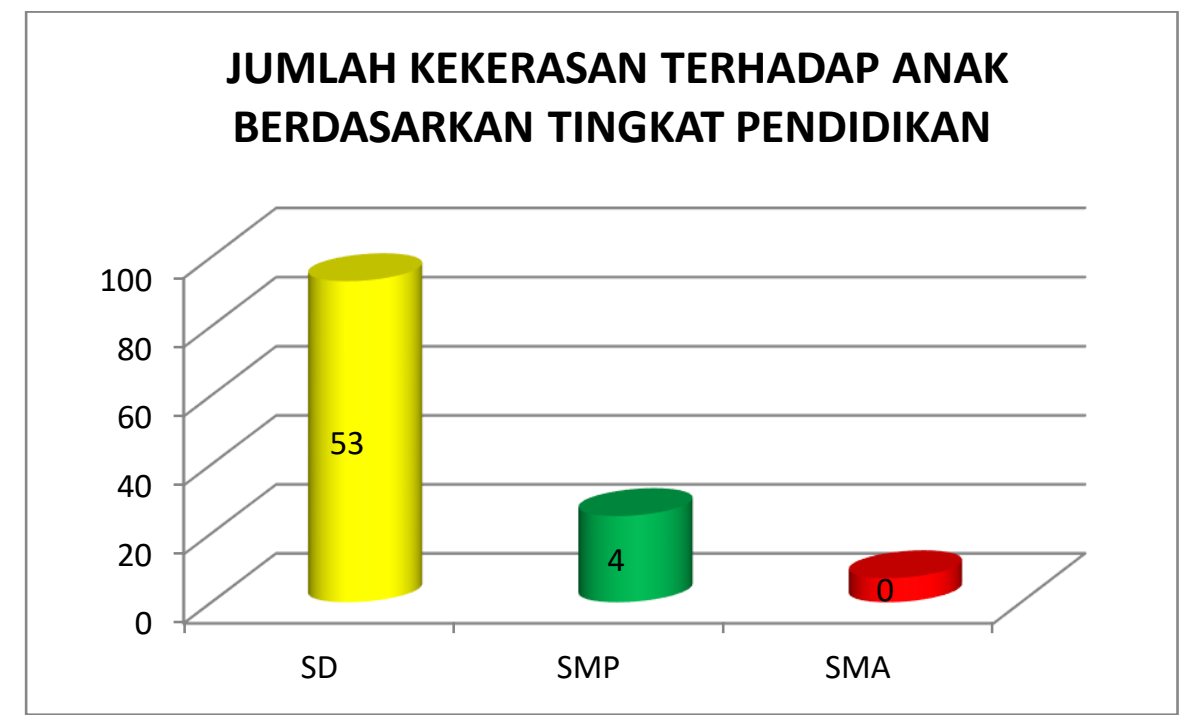

Gambar 1. Pemetaan Korban Kekerasan Anak Berdasarkan Tingkat Pendidikan

Dilihat dari grafik di atas menunjukan bahwa tindakan kekerasan terhadap anak lebih rentan terjadi pada korban di tingkat Sekolah Dasar (SD) berjumlah 53 kasus dan tindakan kekerasan terhadap anak di Sekolah Menengah Pertama (SMP) ada 4 kasus, sedangkan kekerasan terhadap anak tidak rentan terjadi pada tingkat pendidikan sekolah menengah atas (SMA). Itu artinya bahwa tingginya jumlah kekerasan terhadap anak lebih rentan terjadi pada anak di bangku Sekolah Dasar (SD).

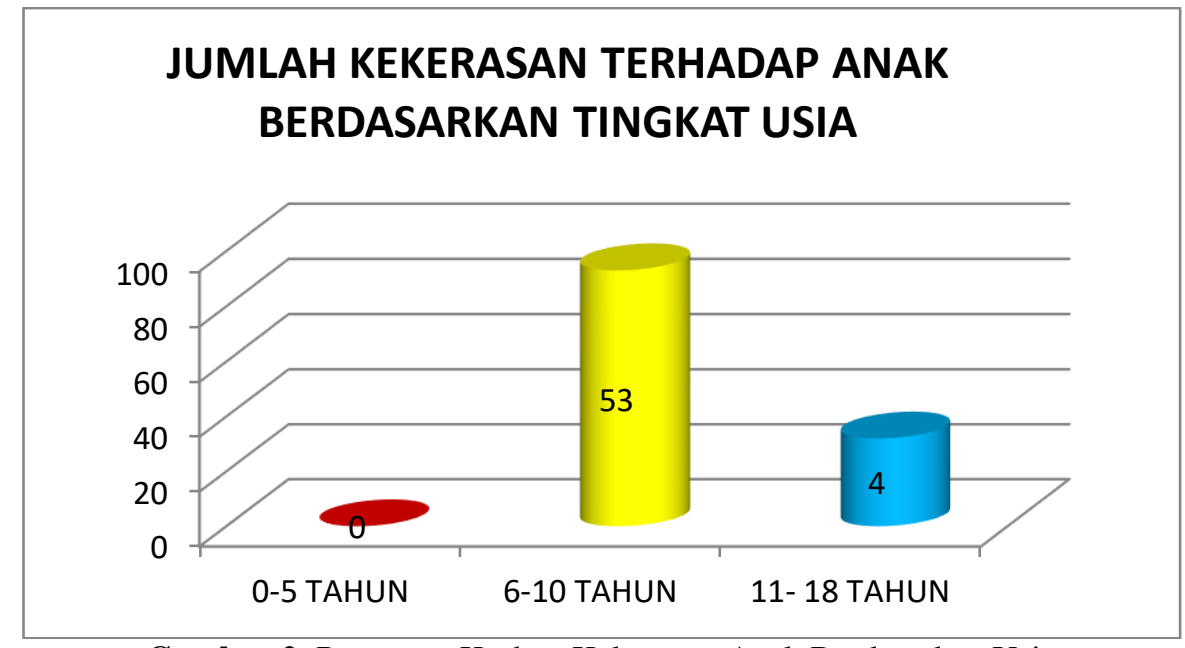

Gambar 2. Pemetaan Korban Kekerasan Anak Berdasarkan Usia

Berdasarkan grafik di atas dapat dijelaskan bahwa tindakan kekerasan terhadap anak lebih banyak terjadi pada anak dengan tingkatan usia antara 6-10 Tahun, kemudian di usia $11-18$ Tahun berada pada urutan kedua. Khusus di Kecamatan Tobelo, Penulis belum menemukan kasus kekerasan yang menimpah anak usia 0 - 5 Tahun. Dari data di atas menunjukkan bahwa tingginya kekerasan terhadap anak masih rentan terjadi pada anak usia 6 - 10 Tahun.

\section{Perspektif Kriminologi Terhadap Kekerasan Anak}

Kriminologi merupakan cabang dari ilmu hukum pidana yang khusus membicarakan soal kejahatan tetapi dari aspek penyebab terjadinya kejahatan dan reaksi masyarakat terhadap kejahatan. Kriminologi sangat berbeda dengan hukum pidana meskipun objek kajiannya adalah kejahatan. Kriminologi digunakan untuk memberi petunjuk dan pedoman bagaimana masyarakat dapat menanggulangi serta menghindari kejahatan dengan baik. Hal tersebut sejalan dengan apa yang dikatakan Topo Santoso ${ }^{15}$, bahwa kriminologi merupakan ilmu yang membahas tentang kejahatan dan penjahat. Dengan demikian maka ketika berbicara soal kriminologi selalu saja dikaitkan dengan hukum pidana.

Ketika membicarakan sesuatu hal yang dilihat dari kacamata hukum pidana, maka pasti akan dibicarakan soal esensi dari pembahasan hukum pidana yakni terkait perbuatan pidana atau asas legalitas, pertanggungjawaban pidana

${ }^{15}$ Topo Santoso, Kriminologi, (Jakarta: Raja Grafindo Persada, 2001), hlm. 9. 
dan sanksi pidana. Hukum pidana oleh Moeljatno ${ }^{16}$ didefenisikan sebagai himpunan peraturan yang berlaku di suatu negara yang berupa perintah atau larangan, disertai dengan ancaman atau sanksi yang berupa pidana bagi barang siapa yang melanggar larangan atau tidak melaksanakan perintah tersebut; selain itu, hukum pidana juga menentukan kapan dan dalam hal - hal apa kepada mereka yang telah melanggar larangan - larangan itu dapat dikenakan atau dijatuhi pidana sebagaimana yang telah diancamkan; serta menentukan dengan cara bagaimana pengenaan pidana itu dilaksanakan apabila ada orang yang disangka telah melanggar larangan tersebut.

Defenisi tersebut jika dilihat secara detail merupakan pengertian hukum pidana dalam arti luas dimana tidak hanya hukum pidana dalam arti materil tetapi juga hukum pidana dalam arti formil atau hukum acara pidana. Namun, dalam pembahasan tulisan ini hanya memfokuskan pada pengertian hukum pidana dalam arti materil yakni keseluruhan aturan hukum pidana baik yang terdapat dalam KUHP maupun yang terdapat dalam aturan - aturan pidana khusus di luar KUHP yang mengatur soal kekerasan terhadap anak.

Hukum pidana mengenal asas legalitas sebagaimana yang termuat dalam Pasal 1 ayat (1) KUHP ${ }^{17}$ yang menggariskan bahwa suatu perbuatan tidak dapat dipidana tanpa ada aturan sebelumnya. Hal ini mengandung beberapa arti yakni bahwa hukum pidana merupakan hukum yang tertulis, untuk menentukan perbuatan tidak boleh menggunakan analogi dan hukum pidana tidak berlaku surut. Atas dasar ini, maka orang baru bisa dipidana melakukan kekerasan terhadap anak jika perbuatan tersebut telah diatur dalam suatu peraturan perundang-undangan secara tertulis. Selain itu, dalam penegakan hukum pidana terminolgi atau konsep kekerasan terhadap anak tidak boleh menimbulkan beragam interpretasi yang dapat menimbulkan kesulitan dalam proses penegakan hukum.

Sebagaimana data kasus kekerasan terhadap anak yang telah diuraikan dalam sub bab sebelumnya, di Kecamatan Tobelo Kabupaten Halmahera Utara terdapat beberapa jenis perbuatan kekerasan terhadap anak yang dikualifikasikan sebagai bentuk tindak pidana karena perbuatan - perbuatan tersebut telah dirumuskan dan diatur baik dalam KUHP maupun dalam peraturan perundang - undangan khusus di luar KUHP antara lain penganiayaan, penelantaran, pemerkosaan, pelecehan dan kekerasan psikis.

Dalam KUHP, perbuatan kekerasan diatur dalam Pasal 89 KUHP yang menyebut membuat orang pingsan atau tidak berdaya disamakan dengan menggunakan kekerasan. Hal ini memberikan batasan konsep kekerasan pada sebatas kekerasan fisik; semantara kenyataan yang terjadi di masyarakat bahwa selain kekerasan fisik, bentuk kekerasan lain yang sering terjadi yaitu kekerasan seksual, kekerasan psikologis, kekerasan politis bahkan kekerasan ekonomi.

Selain kekerasan fisik, di bagian lain KUHP mengatur perihal kekerasan dimana perempuan dan anak sebagai korban yakni terdapat dalam Pasal 281 dan Pasal 282 KUHP terkait kejahatan kesusilaan dan pornografi, Pasal 285 KUHP terkait kejahatan perkosaan, Pasal 290 KUHP terkait kejahatan percabulan, Pasal 297 KUHP terkait kejahatan perdagangan wanita, Pasal 328 KUHP terkait kejahatan penculikan dan Pasal 351 KUHP terkait kejahatan penganiayaan.

Pasal-pasal KUHP tersebut diuraikan dalam isi pasal sebagai berikut:

Pasal 281 KUHP yang merupakan bagian pokok delik kesusilaan yang meliputi Pasal 282 di dalamnya, berbunyi diancam dengan pidana penjara paling lama dua tahun delapan bulan atau pidana denda paling banyak empat ribu lima ratus rupiah:

1. Barangsiapa dengan sengaja dan terbuka melanggar kesusilaan;

2. Barangsiapa dengan sengaja dan di depan orang lain yang ada di situ bertentangan dengan kehendaknya, melanggar kesusilaan.

Terkait kejahatan perkosaan terdapat dalam Pasal 285 KUHP berbunyi:

"Barang siapa dengan kekerasan atau ancaman kekerasan memaksa seorang wanita bersetubuh dengan dia di luar perkawinan, diancam karena melakukan perkosaan dengan pidana penjara paling lama dua belas tahun"

Terkait kejahatan percabulan diatur dalam Pasal 290 KUHP yang berbunyi:

Diancam dengan pidana penjara selama tujuh tahun:

1. Barangsiapa melakukan perbuatan cabul dengan seseorang, padahal diketahuinya bahwa orang itu pingsan atau tidak berdaya;

2. Barangsiapa melakukan perbuatan cabul dengan seseorang padahal diketahuinya atau sepatutnya harus diduganya, bahwa umurnya belum lima belas tahun atau kalau umurnya tidak jelas, yang bersangkutan belum waktunya untuk dikawin.

Seterusnya terkait kejahatan perdagangan wanita diatur dalam Pasal 297 KUHP yang berbunyi: perdagangan perempuan dan perdagangan anak laki-laki yang belum dewasa, diancam dengan pidana penjara paling lama enam tahun.

\footnotetext{
${ }^{16}$ Moeljatno, Asas - Asas Hukum Pidana, (Jakarta: Rineka Cipta, 2008), hlm. 2.

${ }^{17}$ Gerry Muhamad Rizky, KUHP dan KUHAP, (Jakarta: Permata Press, 2008), hlm. 11.
} 
Terkait kejahatan penculikan diatur dalam Pasal 328 KUHP yang berbunyi:

"Barangsiapa membawa pergi seorang dari tempat kediamannya atau tempat tinggalnya sementara dengan maksud untuk menempatkan orang itu secara melawan hukum di bawah kekasaannya atau kekuasaan orang lain, atau untuk menempatkan dia dalam keadaan sengsara, diancam karena penculikan dengan pidana penjara paling lama dua belas tahun".

Seterusnya terkait kejahatan penganiayaan diatur dalam Pasal 351 KUHP yang berbunyi:

1. Penganiayaan diancam dengan pidana penjara paling lama dua tahun delapan bulan dan pidana denda paling banyak empat ribu lima ratus rupiah;

2. Jika perbuatan mengakibatkan luka-luka berat, yang bersalah diancam dengan pidana penjara paling lama lima tahun;

3. Jika mengakibatkan mati, diancam dengan pidana penjara paling lama tujuh tahun;

4. Dengan penganiayaan disamakan sengaja merusak kesehatan;

5. Percobaan melakukan kejahatan ini tidak dipidana.

Jika ditelaah secara detail, kekerasan fisik merupakan perbuatan kekerasan yang paling banyak diatur dalam pasal-pasal KUHP. Selain itu, dari pasal - pasal yang mengatur soal kekerasan tersebut, sebagian besar pasal ditujukan untuk perlindungan manusia secara umum dan sedikit saja pasal yang merujuk pada perlindungan perempuan dan anak sebagai korban. Pasal yang khusus mengatur perlindungan terhadap perempuan sebagai korban kekerasan hanyalah Pasal 285 KUHP tentang kejahatan perkosaan dan Pasal 297 tentang kejahatan perdagangan perempuan; lain daripada itu, semua pasal berlaku untuk semua orang termasuk terhadap anak.

Selain KUHP, perbuatan kekerasan terhadap anak secara normatif diatur dalam beberapa peraturan khusus yakni Undang - Undang Nomor 23 Tahun 2004 tentang Penghapusan Kekerasan Dalam Rumah Tangga dimana termuat dalam beberapa pasal di antaranya Pasal 5 yang berbunyi:

Setiap orang dilarang melakukan kekerasan dalam rumah tangga terhadap orang dalam lingkup rumah tangganya, dengan cara:
a. Kekerasan fisik
b. Kekerasan psikis
c. Kekerasan seksual atau
d. Penelantaran rumah tangga.

Pasal tersebut mengandung arti bahwa kekerasan dalam lingkup rumah tangga termasuk juga di dalamnya kekerasan yang dilakukan terhadap anak. Selanjutnya dalam Pasal 6 Undang-Undang Nomor 23 Tahun 2004 disebutkan bahwa kekerasan fisik sebagaimana dimaksud dalam Pasal 5 huruf a adalah perbuatan yang mengakibatkan rasa sakit, jatuh sakit atau luka berat. Seterusnya dalam Pasal 7 Undang-Undang Nomor 23 Tahun 2004 disebutkan bahwa yang dimaksud dengan kekerasan psikis sebagaimana dimaksud dalam Pasal 5 huruf b adalah perbuatan yang mengakibatkan ketakutan, hilangnya rasa percaya diri, hilangnya kemampuan untuk bertindak, rasa tidak berdaya, dan/atau penderitaan psikis berat pada seseorang. Seterusnya dalam Pasal 8 Undang-Undang Nomor 23 Tahun 2004 disebutkan bahwa yang dimaksud dengan kekerasan seksual sebagaimana dimaksud dalam Pasal 5 huruf c meliputi pertama, pemaksaan hubungan seksual yang dilakukan terhadap orang yang menetap dalam lingkup rumah tangga tersebut; kedua, pemaksaan hubungan seksual terhadap salah seorang dalam lingkup rumah tangganya dengan orang lain untuk tujuan komersial dan/atau tujuan tertentu. Selain itu, masih terkait dengan kekerasan, Pasal 9 UndangUndang Nomor 23 Tahun 2004 menyebut bahwa pertama, setiap orang dilarang menelantarkan orang dalam lingkup rumah tangganya, padalah menurut hukum yang berlaku baginya atau karena persetujuan atau perjanjian ia wajib memberikan kehidupan, perawatan, atau pemeliharaan kepada orang tersebut; kedua, penelantaran juga berlaku bagi setiap orang yang mengakibatkan ketergantungan ekonomi dengan cara membatasi dan/atau melarang untuk bekerja yang layak di dalam atau di luar rumah sehingga korban berada di bawah kendali orang tersebut.

Selain itu, terkait dengan ketentuan pidana bagi pelaku kekerasan dalam rumah tangga termasuk kekerasan terhadap anak, diatur dalam Pasal 44, Pasal 45, Pasal 46, Pasal 47, Pasal 48 dan Pasal 49 Undang- Undang Nomor 23 Tahun 2004 sebagai berikut.

Pasal 44 berbunyi:

(1) Setiap orang yang melakukan perbuatan kekerasan fisik dalam lingkup rumah tangga sebagaimana dimaksud dalam Pasal 5 huruf a dipidana dengan pidana penjara paling lama 5 (lima) tahun atau denda paling banyak Rp 15.000.000,00 (lima belas juta rupiah).

(2) Dalam hal perbuatan sebagaimana dimaksud pada ayat (1) mengakibatkan korban mendapat jatuh sakit atau luka berat, dipidana dengan pidana penjara paling lama 10 (sepuluh) tahun atau denda paling banyak $\mathrm{Rp}$ 30.000.000,00 (tiga puluh juta rupiah). 
(3) Dalam hal perbuatan sebagaimana dimaksud pada ayat (2) mengakibatkan matinya korban, dipidana dengan pidana penjara paling lama 15 (lima belas) tahun atau denda paling banyak Rp 45.000.000,00 (empat puluh lima juta rupiah).

Pasal 45 ayat (1) berbunyi:

Setiap orang yang melakukan perbuatan kekerasan psikis dalam lingkup rumah tangga sebagaimana dimaksud dalam Pasal 5 huruf b dipidana dengan pidana penjara paling lama 3 (tiga) tahun atau denda paling banyak Rp 9.000.000,00 (sembilan juta rupiah).

\section{Pasal 46 berbunyi:}

Setiap orang yang melakukan perbuatan kekerasan seksual sebagaimana dimaksud dalam Pasal 8 huruf a dipidana dengan pidana penjara paling lama 12 (dua belas) tahun atau denda paling banyak Rp 36.000.000,00 (tiga puluh enam juta rupiah).

\section{Pasal 47 berbunyi:}

Setiap orang yang memaksa orang yang menetap dalam rumah tangganya melakukan hubungan seksual sebagaimana dimaksud dalam Pasal 8 huruf b dipidana dengan pidana penjara paling singkat 4 (empat) tahun dan pidana penjara paling lama 15 (lima belas) tahun atau denda paling sedikit Rp 12.000.000,00 (dua belas juta rupiah) atau denda paling banyak Rp 300.000.000,00 (tiga ratus juta rupiah).

\section{Pasal 48 berbunyi:}

Dalam hal perbuatan sebagaimana dimaksud dalam Pasal 46 dan Pasal 47 mengakibatkan korban mendapat luka yang tidak memberi harapan akan sembuh sama sekali, mengalami gangguan daya pikir atau kejiwaan sekurangkurangnya selama 4 (empat) minggu terus menerus atau 1 (satu) tahun tidak berturut-turut, gugur atau matinya janin dalam kandungan, atau mengakibatkan tidak berfungsinya alat reproduksi, dipidana dengan pidana penjara paling singkat 5 (lima) tahun dan pidana penjara paling lama 20 (dua puluh) tahun atau denda paling sedikit Rp 25.000.000,00 (dua puluh lima juta rupiah) dan denda paling banyak Rp 500.000.000,00 (lima ratus juta rupiah).

\section{Pasal 49 berbunyi:}

Dipidana dengan pidana penjara paling lama 3 (tiga) tahun atau denda paling banyak Rp 15.000.000,00 (lima belas juta rupiah), setiap orang yang :

a. menelantarkan orang lain dalam lingkup rumah tangganya sebagaimana dimaksud dalam Pasal 9 ayat (1);

b. menelantarkan orang lain sebagaimana dimaksud dalam Pasal 9 ayat (2).

Perihal kekerasan terhadap anak serta perlindungan hukum bagi anak, ada pula diatur dalam Undang - Undang Nomor 35 Tahun 2014 perubahan Undang - Undang Nomor 23 Tahun 2002 tentang Perlindungan Anak, termuat dalam beberapa pasal yang diuraikan sebagai berikut:

Pasal 76A berbunyi setiap orang dilarang:

a. memperlakukan Anak secara diskriminatif yang mengakibatkan Anak mengalami kerugian, baik materiil maupun moril sehingga menghambat fungsi sosialnya; atau

b. memperlakukan Anak Penyandang Disabilitas secara diskriminatif.

Pasal 76D berbunyi:

Setiap Orang dilarang melakukan Kekerasan atau ancaman Kekerasan memaksa Anak melakukan persetubuhan dengannya atau dengan orang lain.

Pasal 76E berbunyi:

Setiap Orang dilarang melakukan Kekerasan atau ancaman Kekerasan, memaksa, melakukan tipu muslihat, melakukan serangkaian kebohongan, atau membujuk Anak untuk melakukan atau membiarkan dilakukan perbuatan cabul.

\section{Pasal 77 berbunyi:}

Setiap Orang yang melanggar ketentuan sebagaimana dimaksud dalam Pasal 76A dipidana dengan pidana penjara paling lama 5 (lima) tahun dan/atau denda paling banyak Rp. 100.000.000,00 (seratus juta rupiah). 


\section{Pasal 78 berbunyi:}

Setiap orang yang mengetahui dan sengaja membiarkan anak dalam situasi darurat sebagaimana dimaksud dalam Pasal 60, anak yang berhadapan dengan hukum, anak dari kelompok minoritas dan terisolasi, anak yang tereksploitasi secara ekonomi dan/atau seksual, anak yang diperdagangkan, anak yang menjadi korban penyalahgunaan narkotika, alkohol, psikotropika, dan zat adiktif lainnya (napza), anak korban penculikan, anak korban perdagangan, atau anak korban kekerasan sebagaimana dimaksud dalam Pasal 59, padahal anak tersebut memerlukan pertolongan dan harus dibantu, dipidana dengan pidana penjara paling lama 5 (lima) tahun dan/atau denda paling banyak Rp 100.000.000,00 (seratus juta rupiah).

\section{Pasal 80 berbunyi:}

(1) Setiap Orang yang melanggar ketentuan sebagaimana dimaksud dalam Pasal 76C, dipidana dengan pidana penjara paling lama 3 (tiga) tahun 6 (enam) bulan dan/atau denda paling banyak Rp72.000.000,00 (tujuh puluh dua juta rupiah).

(2) Dalam hal Anak sebagaimana dimaksud pada ayat (1) luka berat, maka pelaku dipidana dengan pidana penjara paling lama 5 (lima) tahun dan/atau denda paling banyak Rp100.000.000,00 (seratus juta rupiah).

(3) Dalam hal Anak sebagaimana dimaksud pada ayat (2) mati, maka pelaku dipidana dengan pidana penjara paling lama 15 (lima belas) tahun dan/atau denda paling banyak Rp3.000.000.000,00 (tiga miliar rupiah).

(4) Pidana ditambah sepertiga dari ketentuan sebagaimana dimaksud pada ayat (1), ayat (2), dan ayat (3) apabila yang melakukan penganiayaan tersebut Orang Tuanya.

\section{Pasal 81 berbunyi:}

(1) Setiap orang yang melangggar ketentuan sebagaimana dimaksud dalam Pasal 76D dipidana dengan pidana penjara paling singkat 5 (lima) tahun dan paling lama 15 (lima belas) tahun dan denda paling banyak Rp5.000.000.000,00 (lima miliar rupiah).

(2) Ketentuan pidana sebagaimana dimaksud pada ayat (1) berlaku pula bagi Setiap Orang yang dengan sengaja melakukan tipu muslihat, serangkaian kebohongan, atau membujuk Anak melakukan persetubuhan dengannya atau dengan orang lain.

(3) Dalam hal tindak pidana sebagaimana dimaksud pada ayat (1) dilakukan oleh Orang Tua, Wali, pengasuh Anak, pendidik, atau tenaga kependidikan, maka pidananya ditambah 1/3 (sepertiga) dari ancaman pidana sebagaimana dimaksud pada ayat (1).

\section{Pasal 82 berbunyi:}

(1) Setiap orang yang melanggar ketentuan sebagaimana dimaksud dalam Pasal 76E dipidana dengan pidana penjara paling singkat 5 (lima) tahun dan paling lama 15 (lima belas) tahun dan denda paling banyak Rp. 5.000.000.000,00 (lima miliar rupiah).

(2) Dalam hal tindak pidana sebagaimana dimaksud pada ayat (1) dilakukan oleh Orang Tua, Wali, pengasuh Anak, pendidik, atau tenaga kependidikan, maka pidananya ditambah $1 / 3$ (sepertiga) dari ancaman pidana sebagaimana dimaksud pada ayat (1).

\section{Pasal 83 berbunyi:}

Setiap orang yang melanggar ketentuan sebagaimana dimaksud dalam Pasal 76F dipidana dengan pidana penjara paling singkat 3 (tiga) tahun dan paling lama 15 (lima belas) tahun dan denda paling sedikit Rp60.000.000,00 (enam puluh juta rupiah) dan paling banyak Rp. 300.000.000,00 (tiga ratus juta rupiah).

\section{Pasal 88 berbunyi:}

Setiap Orang yang melanggar ketentuan sebagaimana dimaksud dalam Pasal 76I, dipidana dengan pidana penjara paling lama 10 (sepuluh) tahun dan/atau denda paling banyak Rp. 200.000.000,00 (dua ratus juta rupiah).

Semua norma hukum dan ketentuan pidana sebagaimana telah diuraikan tersebut ditujukan untuk melindungi anak dari berbagai bentuk perbuatan kekerasan baik fisik maupun psikis sehingga pelaku yang melakukannya dapat dimintai pertanggungjawaban melalui hukum pidana. Sejalan dengan hal itu, Hanafi Mahrus ${ }^{18}$ menyebut konsep pertanggungjawaban pidana sesungguhnya tidak hanya menyangkut soal hukum semata - mata melainkan juga menyangkut soal nilai - nilai moral atau kesusilaan umum yang dianut oleh suatu masyarakat atau kelompok kelompok dalam masyarakat, hal ini dilakukan agar pertanggungjawaban pidana itu dicapai dengan memenuhi

\footnotetext{
${ }^{18}$ Hanafi Mahrus, Sistem Pertanggungjawaban Pidana, (Jakarta: Rajawali Pers, 2015), hlm. 16.
} 
keadilan. Pertanggungjawaban pidana adalah suatu bentuk untuk menentukan apakah seorang tersangka atau terdakwa dipertanggungjawabkan atas suatu tindak pidana yang telah terjadi.

Terkait dengan pertanggungjawaban pidana atas perbuatan kekerasan terhadap anak, hukum pidana Indonesia tidak menggabungkan antara perbuatan pidana dan pertanggujawaban pidana. Kita menganut paham dualistis dan bukan paham monoistis yang mana dalam paham dualistis di dalam defenisi perbuatan pidana tidak meliputi pengertian pertanggungjawaban pidana. Pada hakikatnya pertanggungjawaban pidana adalah suatu keaadaan yang merujuk pada tiga kemampuan yakni pertama, pelaku menyadari perbuatan dan akibatnya; kedua, pelaku menyadari bahwa perbuatan tersebut bertentangan dengan ketertiban umum; dan ketiga, ketika pelaku melakukan perbuatan dia berada dalam kebebasan kehendak. Dilihat dari sudut hukum pidana maka timbulah pertanggungjawaban pidana.

Berkaitan dengan hal tersebut, dalam hukum pidana kesalahan merupakan elemen utama dari pertanggungjawaban pidana. Sejalan dengan hal ini, Teguh Prasetyo ${ }^{19}$ menyebut kesalahan memiliki arti penting sebagai asas tak tertulis dalam hukum positif Indonesia yang menyatakan "tiada pidana tanpa kesalahan". Artinya, untuk dapat dipidananya suatu perbuatan diharuskan adanya kesalahan yang melekat pada diri pembuat untuk dapat dimintai pertanggujawaban atasnya. Atas dasar ini, maka dalam perspektif hukum pidana seorang yang melakukan perbuatan kekerasan terhadap anak meskipun perbuatannya telah diatur dalam undang - undang pidana, belum tentu dapat dimintai pertanggujawaban pidana dan belum tentu dapat dipidana.

Terkait dengan pertanggungjawaban pidana, sedikit terdapat perbedaan jika dilihat dari aspek budaya masyarakat. Masyarakat Kabupaten Halmahera Utara memang masi melekat budaya kekeluargaan yang tinggi sehingga seringkali jika terjadi kekerasan terhadap anak dipandang bukan sebagai bentuk pelanggaran hukum melainkan bentuk didikan orang tua. Menurut Melson Taju Kepala Desa Warino Kecamatan Tobelo dalam wawancara (tanggal 10 Juni 2020) mengatakan bahwa budaya mendidik anak dengan cara dipukul merupakan hal biasa di hampir semua wilayah desa - desa di Kecamatan Tobelo Kabupaten Halmahera Utara, apalagi memukul anak sendiri. Mungkin jika memukul anak orang lain, sering terjadi saling baku lapor. Tetapi sejauh ini jika memukul anak sendiri, belum ada laporan pidana. Faktor yang paling utama terjadinya perbuatan kekerasan terhadap anak adalah karena kurangnya pemahaman atau rendahnya tingkat pendidikan dari orang tua selain itu ada juga faktor budaya masyarakat Halmahera yang terbiasa dengan budaya keras. Hal sejalan juga disampaikan oleh Yufianus Maliong Kepala Desa Wari dan Muhamad Iksan Madu Kepala Desa Rawajaya dalam wawancara (tanggal, 22 Juni 2020) yang menjelaskan bahwa di desa mereka ketika terjadi kekerasan terhadap anak seringkali jarang dilaporkan jika terjadi dalam lingkup rumah tangga sendiri; berbeda jika seorang melakukan kekerasan terhadap anak orang lain. Namun, ada beberapa masyarakat yang saat ini sudah mulai sadar atau tahu hukum karena kebetulan desa kami masuk wilayah kota Tobelo sehingga sudah banyak orang - orang yang punya pendidikan dan mengerti terkait hukum terutama perbuatan kekerasan terhadap anak sehingga ada beberapa kasus memang dilaporkan secara hukum.

Berdasarkan uraian tersebut, maka berbagai undang - undang yang dikeluarkan oleh negara yang mengatur perlindungan terhadap anak dari bentuk kekerasan seperti Undang-Undang RI Nomor 23 Tahun 2002 Tentang Perlindungan Anak, Undang-Undang RI Nomor 35 Tahun 2014 Tentang Perubahan Undang-Undang RI Nomor 23 Tahun 2002 Tentang Perlindungan Anak, Undang - Undang Nomor 23 Tahun 2004 tentang Penghapusan Kekerasan dalam Rumah Tangga, Kitab Undang - Undang Hukum Pidana perlu terus menerus diperkenalkan bagi masyarakat lebih khususnya di wilayah Indonesia Timur seperti di Kabupaten Halmahera Utara, karena faktor rendahnya pendidikan dan pemahaman terkait kekerasan terhadap anak menjadi faktor utama timbulnya kekerasan terhadap anak.

\section{SIMPULAN}

Kekerasan terhadap anak merupakan perbuatan yang bertentangan dengan hukum oleh sebab itu diperlukan kerja sama semua pihak terutama negara dalam mencegah dan melindungi anak dari berbagai bentuk perbuatan kekerasan. Dalam penelitian ini ditemukan beberapa hal pertama, dalam empat tahun terakhir yakni Tahun 2015, Tahun 2016, Tahun 2017 dan tahun 2018, selalu terjadi kasus kekerasan terhadap anak di Kecamatan Tobelo Kabupaten Halmahera Utara dengan jumlah angka yang dinamis yakni terdapat 57 kasus dan jenis kasus bermacam macam berupa kekerasan fisik seperti penganiayaan, pemerkosaan, pelecehan, penelantaran dan kekerasan psikis. Kedua, kekerasan terhadap anak merupakan salah satu kejahatan yang telah diatur dalam hukum pidana sebagai hukum positif Indonesia, baik yang terdapat dalam Kitab Undang - Undang Hukum Pidana (KUHP) maupun dalam Undang - Undang Nomor 23 Tahun 2004 tentang Penghapusan Kekerasan dalam Rumah Tangga dan Undang Undang Nomor 35 Tahun 2014 perubahan Undang - Undang Nomor 23 Tahun 2002 tentang Perlindungan Anak. Ketiga, oleh karena kekerasan terhadap anak merupakan bagian dari kejahatan atau perbuatan pidana, maka pelaku yang melakukan perbuatan ini dapat dimintai pertanggungjawaban pidana. Selain itu, peran serta masyarakat diperlukan untuk berpartisipasi aktif jika menemukan perbuatan kekerasan yang dilakukan terhadap anak di lingkungan sekitar. Keempat, faktor penyebab terjadi kekerasan terhadap anak di Kecamatan Tobelo Kabupaten 
Ernest Sengi dan Alfonsisus Budiman, Kekerasan Terhadap Anak dalam Perspektif Kriminologi Di Kecamatan Tobelo Kabupaten Halmahera Utara

Halmahera Utara adalah kurangnya pemahaman soal jenis perbuatan ini kerena tingkat pendidikan masyarakat yang masih rendah serta kurangnya sosialisasi yang mestinya terus-menerus dilakukan.

\section{DAFTAR PUSTAKA \\ Buku}

Babua, Piet Hein. Kekerasan dalam Rumah Tangga di Kabupaten Halmahera Utara. Tobelo: Balitabang Halut, 2018.

Chazawi, Adami. Pelajaran Hukum Pidana, Bagian 1. Jakarta: Raja Grafindo Persada, 2002.

Mahrus, Hanafi. Sistem Pertanggungjawaban Pidana, Cet. Pertama. Jakarta: Rajawali Pers, 2015.

Marzuki, Peter Mahmud. Penelitian Hukum. Jakarta: Kencana, 2005.

Moeljatno. Asas - Asas Hukum Pidana. Jakarta: Rineka Cipta, 2008.

Nasution, Bahder Johan. Metode Penelitian Hukum. Bandung: Mandar Maju, 2008.

Prasetyo, Teguh. Hukum Pidana. Jakarta: Rajawali Pers, 2013.

Rizky, Gerry Muhamad. KUHP dan KUHAP. Jakarta: Permata Press, 2008.

Santoso, Topo. Kriminologi. Jakarta: Raja Grafindo Persada, 2001.

Soekanto, Soerjono. Penelitian Hukum Normatif, Suatu Tinjauan Singkat. Jakarta: Raja Grafindo Persada, 2012.

Waluyo, Bambang. Pidana dan Pemidanaan. Jakarta: Sinar Grafika, 2008.

\section{Jurnal}

Andini, Thathit Manon, dkk. "Identifikasi Kejadian Kekerasan pada Anak di Kota Malang Identification of Violence in Children in Malang City", Jurnal Perempuan dan Anak (JPA), Volume 2, Nomor 1, (Februari 2019) : 15.

Anjari, Warih. "Fenomena Kejahatan Sebagai Bentuk Kekerasan (Violence)", Jurnal Widya Yustisia, Volume 1, Nomor 1, (April 2014) : 43.

Kobandaha, Mahmudin. "Perlindungan Hukum Terhadap Anak Korban Kekerasan Dalam Rumah Tangga Dalam Sistem Hukum Di Indonesia”, Jurnal Hukum Unsrat, Volume 23, Nomor 8, (Januari 2017) : 85.

Pasalbessy, J. D. "Dampak Tindak Kekerasan Terhadap Perempuan dan Anak Serta Solusinya", Jurnal Sasi, Volume 16, Nomor 3, (Juli 2010) : 9.

Prasetyo, Teguh. "Penerapan Diversi Terhadap Tindak Pidana Anak Dalam Sistem Peradilan Pidana Anak" Jurnal Refleksi Hukum, Volume 9, Nomor 1, (April 2015) : 6.

Utami, Penny Naluria. "Pencegahan Kekerasan Terhadap Anak dalam Perspektif Hak atas Rasa Aman di Nusa Tenggara Barat", Jurnal HAM, Volume 9, Nomor 1, (Juli 2018) : 9.

\section{Peraturan Perundang-Undangan dan Sumber Lain}

Undang-Undang RI Nomor 23 Tahun 2002 Tentang Perlindungan Anak.

Undang-Undang RI Nomor 35 Tahun 2014 Tentang Perubahan Undang-Undang RI Nomor 23 Tahun 2002 Tentang Perlindungan Anak.

Undang-Undang RI Nomor 12 Tahun 2011 Tentang Sistem Peradilan Pidana Anak.

Laporan Dinas Perlindungan Perempuan, Perlindungan Anak dan Keluarga Berencana Kab. Halmahera Utara Tahun $2015-2019$. 